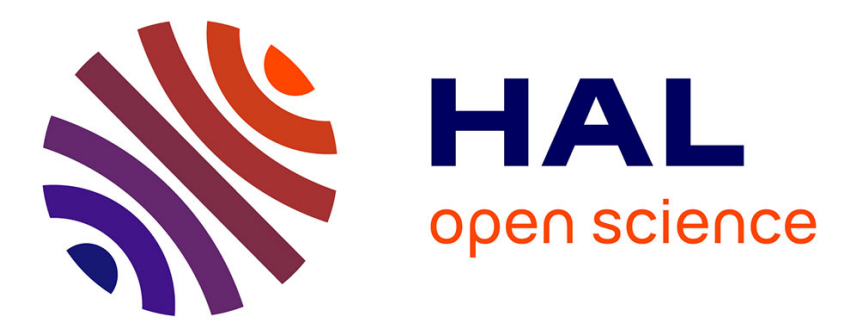

\title{
Contribution of phytoliths to the suspended load of biogenic silica in the Nyong basin rivers (Cameroon)
}

Lise Cary, Anne Alexandre, Jean-Dominique Meunier, Jean-Loup Boeglin, Jean-Jacques Braun

\section{- To cite this version:}

Lise Cary, Anne Alexandre, Jean-Dominique Meunier, Jean-Loup Boeglin, Jean-Jacques Braun. Contribution of phytoliths to the suspended load of biogenic silica in the Nyong basin rivers (Cameroon). Biogeochemistry, 2005, 74 (1), pp.101 - 114. 10.1007/s10533-004-2945-1 . hal-01909688

\section{HAL Id: hal-01909688 \\ https://hal.science/hal-01909688}

Submitted on 14 Dec 2018

HAL is a multi-disciplinary open access archive for the deposit and dissemination of scientific research documents, whether they are published or not. The documents may come from teaching and research institutions in France or abroad, or from public or private research centers.
L'archive ouverte pluridisciplinaire HAL, est destinée au dépôt et à la diffusion de documents scientifiques de niveau recherche, publiés ou non, émanant des établissements d'enseignement et de recherche français ou étrangers, des laboratoires publics ou privés. 


\title{
Contribution of phytoliths to the suspended load of biogenic silica in the Nyong basin rivers (Cameroon)
}

\author{
LISE CARY $Y^{1,2}$, ANNE ALEXANDRE ${ }^{1}$, JEAN-DOMINIQUE \\ MEUNIER $^{1, *}$, JEAN-LOUP BOEGLIN ${ }^{3}$ and \\ JEAN-JACQUES BRAUN ${ }^{4}$ \\ ${ }^{1}$ CEREGE, Europôle de l'Arbois, BP 80, 13545 Aix-en-Provence, France, ${ }^{2} I N R A$, UR de Géochimie \\ des sols et des eaux, BP 8013545 Aix-en-Provence, cedex 4, France; ${ }^{3} L M T G, U M R$ 5563, 38, rue des \\ 36 ponts, 31300 Toulouse, France; ${ }^{4}$ Indian Institute of Science, Indo-French Cell for Water Sciences, \\ 560012 Bangalore, India; *Author for correspondence (e-mail: meunier@cerege.fr)
}

Received 30 October 2003; revised in accepted form 6 September 2004

Key words: biogenic silica, phytolith, weathering, erosion, Cameroon

\begin{abstract}
Particulate biogenic silica (BSi) carried by rivers to estuaries and marine sediments is generally assumed to be primarily composed of diatoms. Phytoliths - biogenic opal formed in plants - are found in some marine sediments where they are interpreted to be the result of atmospheric and river inputs. In this study, we evaluate the contribution of phytoliths to the suspended load of rivers of the Nyong basin (Cameroon). BSi ( $2 \mu \mathrm{m}$ to $2 \mathrm{~mm}$ fraction) in the soils and the rivers range respectively, from 0.9 to $3.9 \mathrm{wt} \%$ and from 1.3 to $4 \mathrm{wt} \%$. About $90 \%$ of the BSi pool in both soils and river suspended load are composed of phytoliths. Thecamoebians and fresh water diatoms are minor components. The concentrations of BSi and the phytolith assemblages show great similarities between the waters and the soil samples. This result implies that the erosion of top soils is the major source of the suspended load, in good agreement with the transport-limited weathering regime of the study basin.
\end{abstract}

\section{Introduction}

Weathering of silicates on the earth's surface is a key factor in global change because it acts as a sink for atmospheric $\mathrm{CO}_{2}$ and represents the major source of dissolved silica in the ocean for diatom growth (Tréguer et al. 1995; Harrison 2000; Moulton et al. 2000). Despite abundant literature on the mechanisms of silicate weathering, the continental biogeochemical cycle of silica is poorly constrained (Meunier et al. 2001; Conley 2002).

Dissolved silica in rivers mainly originates from the weathering of continental silicates (Bluth and Kump 1994). Conley (1997) calculated from volumeweighted averaging (Meybeck 1988) that $16 \%$ of the river suspended load of silica is delivered to the ocean as biogenic silica (BSi). BSi in sediments is generally measured using hot alkaline solutions (DeMaster 1981; Conley 1997, 2002; Michalopoulos and Aller 2004). This approach assumes that BSi is mainly composed of diatoms. Phytoliths - amorphous silica particles formed in plants - are a sizeable BSi pool in the global biogeochemical silica cycle 
(Conley 2002). Phytoliths in soils commonly range from less than 1 to $30 \mathrm{~g} / \mathrm{kg}$ (Wilding et al. 1989; Alexandre et al. 1997; Runge 1999; Clarke 2003) but can reach $1000 \mathrm{~g} / \mathrm{kg}$ in some soil horizons (Meunier et al. 1999). Using a nondestructive extraction, and a point-counting approach, several authors have shown that phytoliths transported by wind are recovered in significant amount in marine sediments (Melia 1984; Pokras and Mix 1985; Jansen et al. 1989; Piperno 1997; Abrantes 2003).

Although phytoliths have already been observed in the river suspended load (Olivié-Lauquet et al. 2000), they have never been quantified in the BSi pool. Such a quantification of phytoliths would bring new insights on the processes involved in the biogeochemical cycle of $\mathrm{Si}$. In this paper, we analyse the contribution of phytoliths to the suspended load of a tropical basin (Nyong basin, Cameroon) using a non-destructive extraction. This basin was chosen because it has been the object of extensive hydro-geochemical investigations for the last 10 years, which provide key information (soil mineralogical composition, water discharge, total suspended sediment load of the rivers, mineralogical composition of the river suspended sediments, dissolved silica concentration of the rivers) for the interpretation of our data.

\section{Environmental setting of the study area}

The study area is presented in Figure 1. The climate of the area is equatorial, with two rainy seasons from March to May and from September to November. The mean annual rainfall is $1630 \mathrm{~mm}$ (estimated from 1993 to 1995) and the mean annual air temperature is $24^{\circ} \mathrm{C} \pm 1$ (Braun et al., in press). The Nyong River basin, the second in size in Cameroon, covers $27,800 \mathrm{~km}^{2}$ between $9^{\circ} 54^{\prime} \mathrm{E}$ and $13^{\circ} 30^{\prime} \mathrm{E}$ of longitude and $2^{\circ} 48^{\prime} \mathrm{N}$ and $4^{\circ} 34^{\prime} \mathrm{N}$ of latitude.

The Nsimi watershed $\left(11^{\circ} 50^{\prime} \mathrm{E}, 3^{\circ} 10^{\prime} \mathrm{N}\right.$, at $120 \mathrm{~km}$ of Yaoundé) is located above a dam on the Mengong River, one of the tributaries of the Nyong River. This small watershed covers 60 ha, and was chosen in 1993 by the French programs PEGI (INSU-CNRS-ORSTOM) and DYLAT (ORSTOM) as an observatory of hydro-biogeochemical cycles in Central Africa.

The geological substratum of the Nsimi watershed is a highly folded $2.8 \mathrm{Ga}$ intermingled granodiorite and monzogranite belonging to the Sangmelina suite (Viers et al. 1997). The Soo and Awout Rivers, tributaries of the Nyong River, follow some of the folds. Both soft saprolite and the fracture network in the hard rock form a large water reservoir (Braun et al. 1998). Depending on the geomorphological position, two weathering covers are observed: (1) convex-rounded hills, characteristic of the erosion surface of the 'South Cameroonian plateau' and (2) swamps of various size (Viers et al. 1997). Convex-rounded hills are covered by polycyclic soil formations reaching $40 \mathrm{~m}$ thick; from bottom to top they are composed of a variegated saprolitic horizon, a ferruginous nodular horizon, and a soft clayey yellow 
(a)

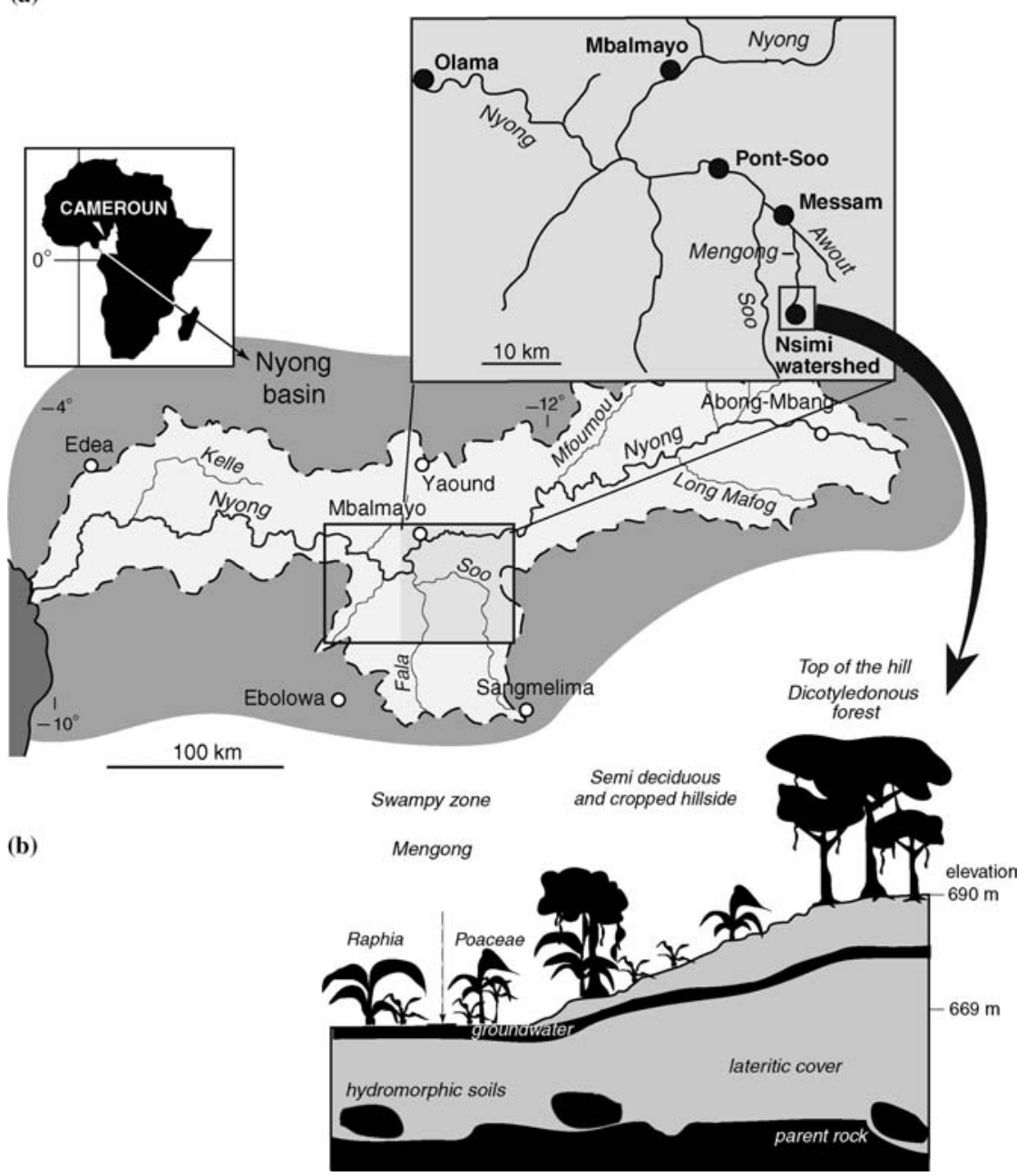

Figure 1. Location of the study area; (a) water samples (black circles) were collected along the Nyong Rivers and its tributaries; (b) soils samples were collected in a cross section along the Nsimi watershed.

horizon. A typical hydromorphic soil profile from swamps is composed of a yellow clayey and sandy horizon at the bottom and a brown, organic-rich, silty-clayey horizon at the top. The mineralogical phases of the soils are represented by residual primary minerals (quartz, K-feldspar) and iron- and aluminium-rich weathering products (kaolinite, goethite and hematite) (Viers et al. 2000). Accessory minerals are mainly Fe-oxides, Ti-oxides and Zircon (Oliva et al. 1999). 
The convex-rounded hills in the Nyong watershed are covered by semideciduous forest $(60 \%)$ and food crops $(40 \%)$. Typical crops are represented by tubers, manioc, peanuts, palm-trees and plantain (Letouzey 1985). Hydromorphic areas represent $20 \%$ of the Nyong watershed area and are preserved from cultivation. Well-drained areas are covered by Caesalpiniaceae and raphia palm-trees while poorly drained areas are covered by raphia palmtrees only. Palm-trees and various species of semi-aquatic Poaceae and Cyperaceae develop in the swamps.

The Mengong is a tributary of the Soo River, the major tributary of the Nyong River. Waters of the Mengong come from hillside groundwater, from swampy areas and from superficial drainage of the rounded hills. Olivié-Lauquet (1996) showed that the Nyon River contains a low suspended load (lower than $3 \mathrm{mg} / \mathrm{l}$ ). The Nyong Basin is characteristic of a 'transport-limited system' (Stallard 1988), due to low tectonic activity, flat morphology and deep weathering profiles, which characterize wide areas of the equatorial zone. The mineralogical composition of the $>0.45 \mu \mathrm{m}$ fraction of the suspended load is essentially composed of quartz, kaolinite and amorphous silica (Olivié-Lauquet 1996).

\section{Field and laboratory techniques}

\section{Soil sampling}

Nine samples were collected from the humic horizon of the soils $(0-10 \mathrm{~cm})$ in 1997, in a cross section along the Mengong River (Figure 1). Samples are named according to their elevation above sea level (in meter): 669.5, 669.8, 670, $671,672,675,680,687,690$. Samples 669.5-672 were sampled in the swampy area. Sample 670 was collected under a palm tree. Samples 675-687 were collected on a slope under palm trees, Poaceae and some dicotyledonous species (abundant at the bottom of the slope). Sample 690 was collected on the top of the hill under a forest cover.

\section{Water sampling}

Five samples of 120-150 1 of water were taken during one of the rainy seasons at (1) Mbalmayo, in the Nyong River (October 2000), (2) Olama in the Nyong outlet (October 2000), (3) Messam in the Awout River (October 2000), (4) Pont-Soo in the Soo River (November 2000) and (5) at the outlet of the Nsimi watershed in the Mengong River (October 2001) (Figure 1a). Two litres of chloroform were added to the water samples in order to stop any biological activity, in particular the bloom of silicon microorganisms. Samples were decanted for $2-3$ weeks in order to concentrate the suspended fraction and poured into 11 bottles for transport. 


\section{Study of amorphous silica particles}

Twenty grams of dried soil samples were sieved at $2 \mathrm{~mm}$. The extraction of amorphous silica particles was made following a wet extraction procedure (Kelly 1990). It consists of the following steps: (1) dissolution of carbonates using $\mathrm{HCl}(1 \mathrm{~N})$; (2) oxidation of organic matter using $\mathrm{H}_{2} \mathrm{O}_{2}(30 \%)$ at $90{ }^{\circ} \mathrm{C}$; (3) removal of the clay fraction $(<2 \mu \mathrm{m})$ by decantation; (4) densimetric separation of opal particles in a heavy liquid of $\mathrm{ZnBr}_{2}\left(\right.$ density of $2.3 \mathrm{~g} / \mathrm{cm}^{3}$ ). Particles were dried and weighed after extraction. For water samples, the suspended load was extracted by centrifugation and weighed before the amorphous silica separation was done, following the procedure applied for soil samples. Concentrations obtained after chemical extraction and weighing are minimal values because a small amount of material may be lost, especially during the heavy liquid extraction. Therefore, the related proportions of extracted particles, calculated after weighing, may be slightly underestimated and represent the amorphous silica load ranging from $2 \mu \mathrm{m}$ to $2 \mathrm{~mm}$.

The amorphous silica particles were mounted in Canada balsam on glass slides and analysed using an optical microscope at $\times 600$ magnification. Microscope observations show that the obtained extractions contain less than $5 \%$ impurities (clays, organic matter). For each slides, the number of particles counted from soil and water samples was, respectively, 225-450 and 100220. Error on concentrations, obtained after double counting of one slide, is $\pm 5 \%$.

Mineralogical and elementary compositions of the samples were determined using X-ray diffraction. Amorphous silica particles were also observed and analysed using a scanning electron microscope (SEM) equipped with an energy dispersive spectrometer (EDS).

\section{Results and discussion}

BSi in soils

The amorphous silica load is entirely composed of BSi. Three types of BSi ( $2 \mu \mathrm{m}$ to $2 \mathrm{~mm}$ fraction) are identified (Table 1) : phytoliths, diatoms and thecamoebians. About $84-94 \%$ of the BSi is composed of phytoliths. The phytoliths concentrations measured in the soils $(0.7-3.5 \mathrm{wt} \%)$ are similar to the phytolith concentrations found in humic horizons of soils in other tropical grasslands and forests (Alexandre et al. 1997; Runge 1999). Thecamoebians are proteozoïc Amoebae living in fresh waters. They are composed of a proteinic testate (agglutinate, siliceous or calcareous) (Ogden and Hedley 1980). They live and reproduce at $\mathrm{pH}$ levels ranging from 3 to 9 (Bonnet 1964). The geometric forms showed in Figure 2a-d) are parts of different silica testate from thecamoebians. Thecamoebians account for $5-13 \%$ of the BSi, with the highest proportions encountered in the swamp and in the lower part of the hillside. 
Table 1. Concentration and composition of the particulate biogenic silica (BSi) (2 $\mu \mathrm{m}$ to $2 \mathrm{~mm}$ fraction) in soils (a) and rivers (b).

\begin{tabular}{|c|c|c|c|c|c|c|}
\hline $\mathrm{BSi}$ & Soil samples & & $(w t \%)$ & $\begin{array}{l}\text { Phytolith/BSi } \\
(\%)\end{array}$ & $\begin{array}{l}\text { Thecamoebian/ } \\
\text { BSi }(\%)\end{array}$ & $\begin{array}{l}\text { Diatom/ } \\
\text { BSi (\%) }\end{array}$ \\
\hline \multicolumn{7}{|l|}{ (a) Soils } \\
\hline \multirow[t]{2}{*}{ Hill top } & 690 & & 1.25 & 94 & 5 & 1 \\
\hline & 687 & & 0.83 & 92 & 6 & 2 \\
\hline \multirow[t]{4}{*}{ Slope } & 680 & & 0.76 & 92 & 8 & 0 \\
\hline & 675 & & 1.23 & 84 & 13 & 3 \\
\hline & 672 & & 0.86 & 87 & 12 & 1 \\
\hline & 671 & & 2.52 & 90 & 9 & 1 \\
\hline \multirow[t]{3}{*}{ Swamps } & 670 & & 2.72 & 91 & 8 & 1 \\
\hline & 669.8 & & 3.32 & 84 & 13 & 3 \\
\hline & 669.5 & & 3.93 & 90 & 9 & 1 \\
\hline \multirow[t]{2}{*}{ (b) Rivers } & & & & & & \\
\hline & $\begin{array}{l}\text { Suspended } \\
\text { load (mg/l) }\end{array}$ & $\begin{array}{l}\text { Dissolved } \\
\mathrm{Si}^{\mathrm{a}}(\mathrm{mg} / \mathrm{l})\end{array}$ & $\begin{array}{l}\mathrm{BSi} \\
(\mathrm{wt} \%)\end{array}$ & $\begin{array}{l}\text { Phytolith/ } \\
\text { BSi (\%) }\end{array}$ & $\begin{array}{l}\text { Thecamoebae/ } \\
\text { BSi }(\%)\end{array}$ & $\begin{array}{l}\text { Diatom/ } \\
\text { BSi (\%) }\end{array}$ \\
\hline $\begin{array}{l}\text { Mengong } \\
\text { Outlet }\end{array}$ & 1.92 & $3.4-4.5$ & 4.07 & 93 & 4 & 3 \\
\hline $\begin{array}{l}\text { Messam } \\
\text { (Awout) }\end{array}$ & 1.86 & $4.2-5.0$ & 1.92 & 89 & 3 & 8 \\
\hline $\begin{array}{l}\text { Pont-Soo } \\
\text { (Soo) }\end{array}$ & 4.27 & $4.2-5.6$ & 1.56 & 99 & 1 & 0 \\
\hline $\begin{array}{l}\text { Mbalmayo } \\
\text { (Nyong) }\end{array}$ & 1.7 & $3.4-4.5$ & 1.6 & 91 & 4 & 5 \\
\hline $\begin{array}{l}\text { Olama } \\
\text { (Nyong) }\end{array}$ & 2.7 & $3-4.8$ & 1.32 & 94 & 5 & 1 \\
\hline
\end{tabular}

${ }^{\mathrm{a} N d a m}$ Ngoupayou (1997).

Diatoms, present in various terrestrial environments including soils (Clarke 2003), are scarce even in the swamp (from 1 to $3 \%$ of $\mathrm{BSi}$ ).

Phytolith assemblages are presented in Figure 3. Phytoliths were classified according to the classification of Twiss (Twiss et al. 1969; Twiss 1992) and the descriptions of Barboni et al. (1999) and Alexandre et al. (1997). Analysis of phytolith assemblages allows us to reconstitute the different original formations. The following phytolith types were encountered in the assemblages: (1) Poaceae types including dumbbell type, mainly produced by the small cells of tall $\mathrm{C} 4$ grasses epidermis, elongate smooth or elongate sinuous, point-shaped and fan-shaped types produced in the epidermis and bulliform-cells of all grasses, (2) rough spherical type produced in the sclerenchym of tropical ligneous dicotyledons, (3) crenate spherical type produced by Palmae, (4) cork-cell like phytolith without any taxonomic significance.

The distribution of Poaceae phytoliths does not vary significantly along the cross section. When phytoliths from short cell of grass epidermis (dumbbell 

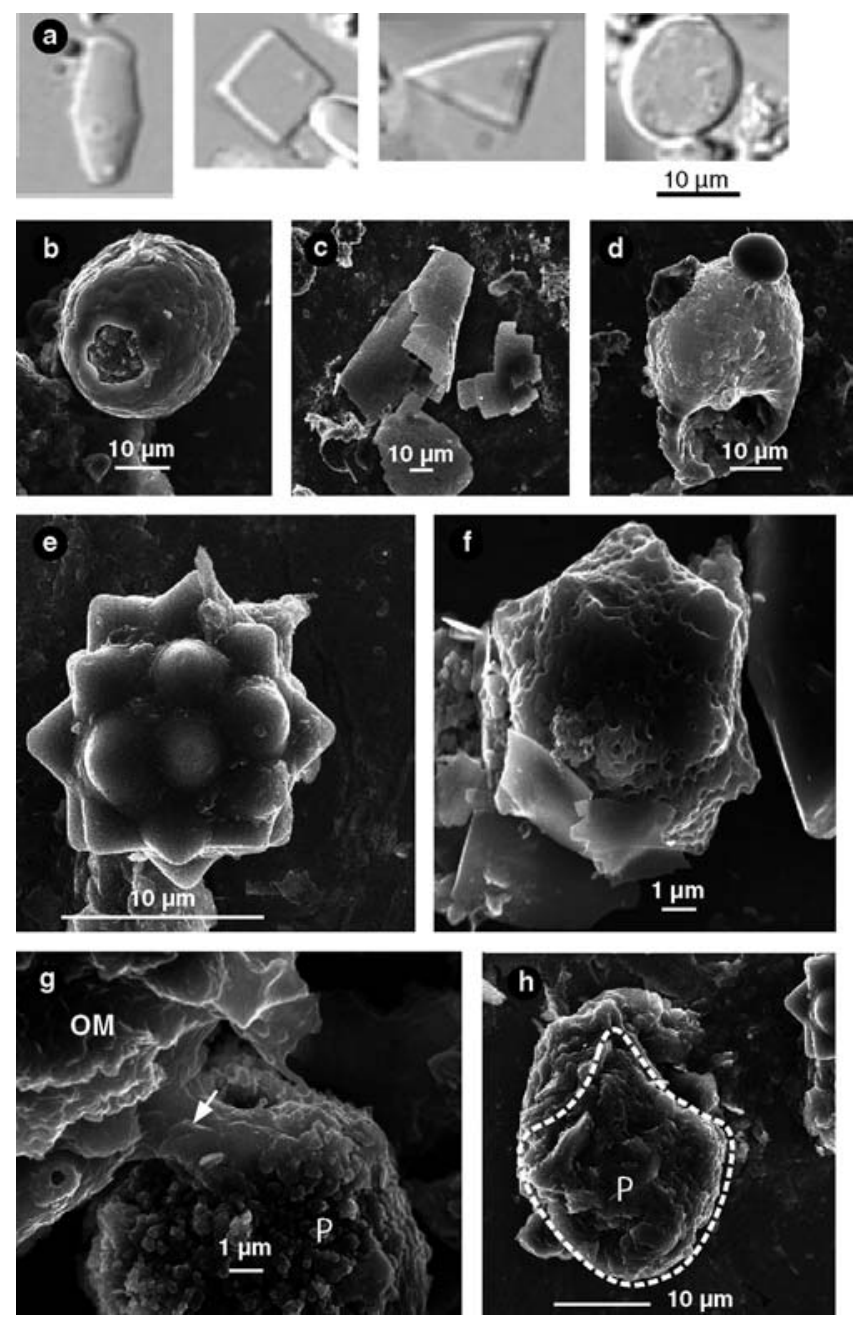

Figure 2. Microscopic observation of BSi particles transported by rivers: (a) various geometric forms of Amoebae testate particles from thecamoebians observed under optical microscopy; (b-d) various Amoebae testate particles under SEM; (e-h) some phytoliths under SEM; (e) a spherical crenate phytolith from Palmae; (f) a spherical crenate phytolith covered by a pitted surface ; (g) a silica bridge (see arrow) between an organo-mineral particle (OM) and a phytolith particle (P); (h) a fan-shaped phytolith $(\mathrm{P})$ covered by clays.

type) are present, the Poaceae assemblages are characteristic of tall $\mathrm{C} 4$ grasses (Fredlund and Tieszen 1994). Proportions of tropical ligneous dicotyledon phytoliths (rough spherical type) are more variable than the Poaceae and Palmae phytolith (crenate spherical type) proportions. In order to better display these fluctuations, phytolith proportions are expressed in terms of ligneous dicotyledon/Poaceae (D/P) and dicotyledon/Palmae (D/Palmae) phytolith 

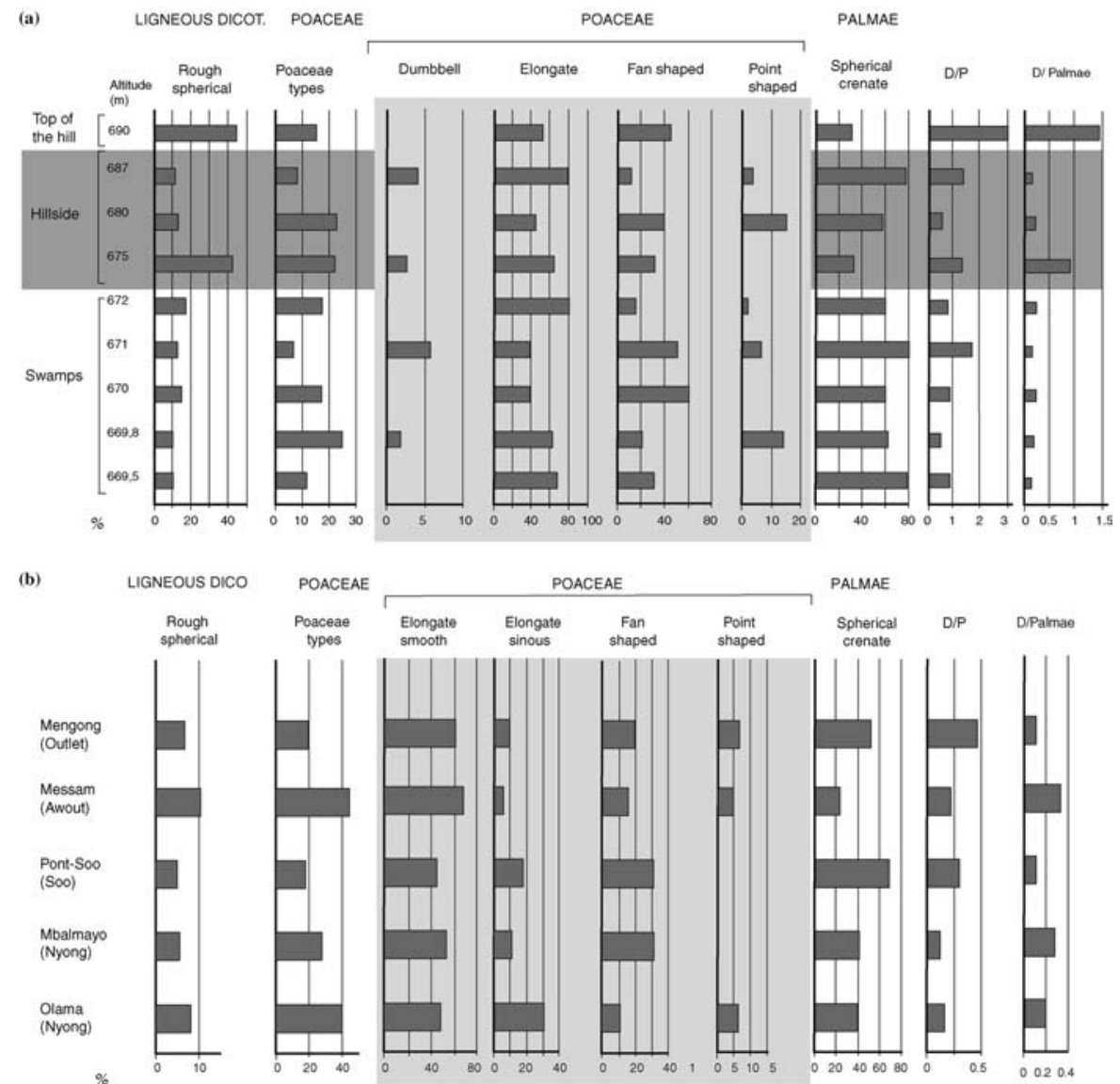

Figure 3. Phytolith assemblages in soil (a) and water (b) samples. Abundance of Poaceae and non-Poaceae phytoliths are calculated taking into account the sum of phytoliths, including the nonunidentified types. $\mathrm{D} / \mathrm{P}$ is the ligneous dicotyledon phytolith (rough spherical)/Poaceae phytolith ratio. D/Palmae is the ligneous dicotyledon phytolith (rough spherical)/Palmae phytolith (spherical crenate) ratio.

ratios (Figure 3). The $\mathrm{D} / \mathrm{P}$ index has proved to be a good indicator of the dicotyledon tree cover density in tropical areas. It is usually lower than 0.5 in tropical grassland assemblages, reaches 1 for secondary tropical forest and goes up to 7 in equatorial forests (Alexandre et al. 1997; Barboni et al. 1999; Brémond et al. 2004a). Phytoliths assemblages found in samples from the slope and swamp soils are characterized by $\mathrm{D} / \mathrm{P}$ ratios ranging from 0.4 to 1.5 and low $\mathrm{D} /$ Palmae ratios ranging from 0.13 to 1.48 . Phytoliths assemblages found in samples from the swamps cannot be distinguished from phytolith assemblages from the slopes. The assemblages from the top of the hill present the highest $\mathrm{D} / \mathrm{P}$ and $\mathrm{D} /$ Palmae ratios, respectively, of 3.07 and 1.48 . 
Phytoliths from samples found in the swamp (samples 672-669.5) are 2-3 times more concentrated than the samples located at higher elevations (675-687). This may suggest that phytolith productivity of grasses and palm trees settled in the swamp is higher. Yet phytolith assemblages of the swamp samples do not show any significant increase of phytoliths from Poaceae and Palmae compared to the samples located above. Consequently, phytoliths have accumulated downwards by physical erosion. This hypothesis is strengthened by the fact that there are no ligneous dicotyledons growing in the swamp while significant amounts of dicotyledon phytoliths were encountered (samples 669.5-672).

BSi in waters

An X-ray diffractogram of the water suspended load displays the occurrence of quartz and kaolinite. A noticeable bump from $10^{\circ} 2$ to $38^{\circ} 2 \theta$ indicates the presence of amorphous silica. These results confirm the previous study of Olivié-Lauquet et al. (2000). Extraction techniques show that the amount of amorphous silica ( $2 \mu \mathrm{m}$ to $2 \mathrm{~mm}$ fraction) ranges from 1.3 to $4 \%$ of the suspended load, in good agreement with the XRD data.

The amorphous silica is entirely composed of BSi with dominant phytoliths (89-99\%, Table 1(b)). These values are similar to the BSi values obtained from the surface soil samples. SEM observation of the suspended load of the Mengong outlet sample shows that phytoliths are transported in waters as (1) isolated particles (Figure 2e,f), (2) linked to other particles by a silica bridge (Figures 2g) and (3) aggregated with other material such as clays (Figure 2h). Dissolution pits on the surface of phytoliths were also observed (Figure 2f). The occurrence of phytoliths with pitted surface were also observed in soil samples (Alexandre et al. 1997; Meunier et al. 1999). Investigation of phytolith assemblages of the water samples shows that they are not significantly different from the assemblages the soils: the Mengong waters and the swamp soil samples contain, respectively, 7 and $10 \%$ of ligneous dicotyledon type, 20 and $10-25 \%$ of Poaceae type and 50 and $60-80 \%$ of palmae type. Slight differences are observed for the other rivers and particularly in their lower $\mathrm{D} / \mathrm{P}$ values. These results could be interpreted as a mixture of phytolith from cultivated areas downstream from the Nsimi watershed. Our data therefore demonstrate that river $\mathrm{BSi}$ is similar to the $\mathrm{BSi}$ found in the top soil of the watershed. This result implies that regional atmospheric input is not an important source of BSi compared to the local physical erosion of soils.

The dissolved $\mathrm{Si}$ from phytoliths can be calculated assuming that the $\mathrm{Si}$ content accounts for $42 \%$ of the phytolith amount $\left(0.37 \mathrm{~mol}\right.$ of $\mathrm{H}_{2} \mathrm{O}$ for $2 \mathrm{~mol}$ of $\mathrm{SiO}_{2}$ ), (Alexandre et al. 1997). Assuming that all phytoliths dissolve, the amount of Si coming from the dissolution of phytoliths ( $2 \mu \mathrm{m}$ to $2 \mathrm{~mm}$ fraction), present in the rivers, ranges from 10.4 to $30.5 \mu \mathrm{g} / 1$ in the Nyong and the Mengong Rivers. These values are very low compared to the total dissolved $\mathrm{Si}$ 
110

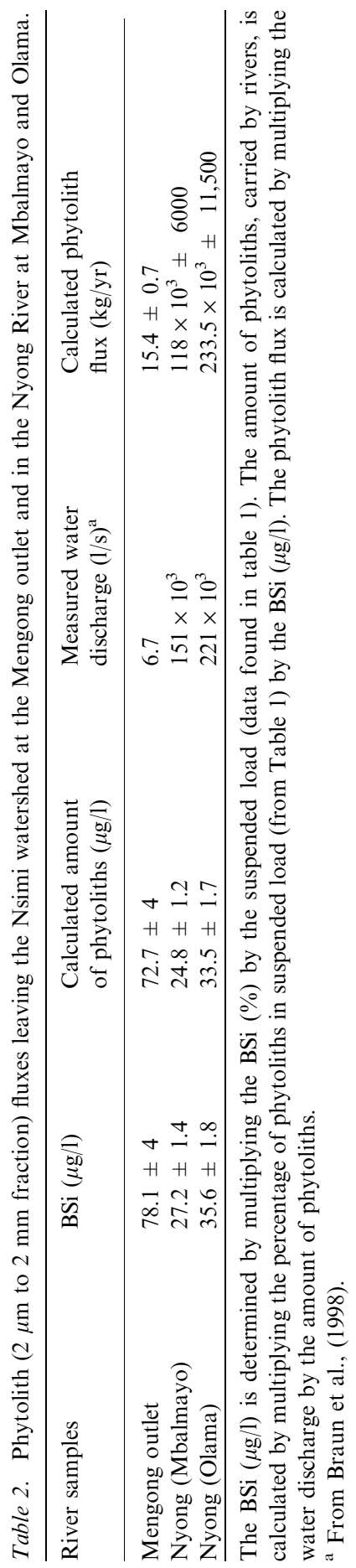


load of 3-5.6 mg/l given by Ndam Ngoupayou (1997) in the entire Nyong watershed. However, the contribution of dissolved silica originating from the dissolution of phytoliths in the soils is unknown. Therefore, the contribution of phytoliths to the dissolved silica concentration in rivers cannot be evaluated.

The calculated BSi concentration of $27.2-78.1 \mu \mathrm{g} / 1$ are lower to values given by Conley (1997) and can be explained by the low physical erosion rate and consequently low suspended matter concentrations in rivers which characterize the Nyong basin. Taking into account the total suspended sediment load for the Nsimi watershed, Braun et al. (in press) found a physical weathering rate of $28 \mathrm{~kg} / \mathrm{ha} / \mathrm{yr}$. If we postulate that the physical erosion affects only the top $10 \mathrm{~cm}$ of the soil where phytoliths are concentrated, we can calculate the output of phytoliths, taking into account the mean phytolith concentration in soils $(1.7 \mathrm{wt} \%$, calculated from Table 1$)$ and the surface of the watershed (60 ha). The calculation gives a phytolith output of $28.5 \mathrm{~kg} / \mathrm{yr}$ which is nearly twice the value of the phytolith flux calculated from the river data at the Mengong outlet (15.4 kg/yr) (Table 2). The difference can be explained by phytolith dissolution or a dilution of only a factor of 2 with deeper soil horizons which are poorer in phytoliths (Alexandre et al. 1997). Our results show that the amount and assemblages of phytoliths in rivers is an indicator of the erosion of the surficial horizons of the soil. The flux of phytoliths increases with water discharge with values of $118 \times 10^{3} \mathrm{~kg} / \mathrm{yr}$ at Mbalmayo and $233.5 \times 10^{3} \mathrm{~kg} / \mathrm{yr}$ at Olama, in the Nyong River.

Are our results expected to hold for other tropical or temperate rivers? A consequence of this study is that the amount of suspended phytoliths in rivers is a good indicator of both phytolith production and soil erosion. High phytolith loads should be found where vegetation is highly productive such as the intertropical low-elevation forests (e.g., Lucas et al. 1993; Alexandre et al. 1997; Wüst and Bustin 2003), and grassy covers (e.g., Meunier et al. 1999; Runge 1999; Alexandre et al. 2000), while temperate and high elevation forests do not produce significant amount of phytoliths (Bartoli, 1986; Bremond et al., 2004b). The second factor which is required for finding significant amount of phytoliths in the particulate load of rivers is that the proportion of material originated from the erosion of soil must be high compared with the load originated from the erosion of parent rocks (devoid of phytoliths). This is clearly the case (1) in intertropical low-elevation (and low-suspended load) zones where the tectonic activity is low and the soils well developed and (2) in areas where human activities (deforestation and agriculture) are highly developed.

\section{Conclusion}

This study demonstrates that $\mathrm{BSi}$ transported by rivers can be essentially composed of phytoliths originating from the erosion of top soils. Phytoliths comprise more than $90 \%$ of BSi ( $2 \mu \mathrm{m}$ to $2 \mathrm{~mm}$ fraction) and can account for $4 \%$ of the entire suspended load (Mengong River). High phytolith loads in 
rivers should be found in the continental areas where the vegetation is highly productive and the erosion of soils is a significant part of the physical erosion. The flux of phytoliths in the suspended load may therefore represent a significant contribution to the global biogeochemical cycle of silica (Conley 2002).

We recommend that non-destructive chemical extraction and microscopy be used in future studies to better define the different biogenic silica particles contained in the suspended load.

\section{Acknowledgements}

This study was supported by the French program PNSE. The authors thank Bruno Gemmiti for his help with thecamoebian identification and Sarah Kirman for helpful discussions.

\section{References}

Abrantes F. 2003. A 340,000 year continental climate record from tropical Africa-news from opal phytoliths from the equatorial Atlantic. Earth Planet. Sci. Lett. 209: 165-179.

Alexandre A., Bouvet M. and Meunier J.-D. 2000. Phytolith and the biochemical cycle of silicon in savanna ecosystem, 3rd I.M.P.R. Man and the (paleo)environment, The phytolith evidence. Tervuren, Belgium, pp. 1-2.

Alexandre A., Meunier J.D., Colin F. and Koud J.M. 1997. Plant impact on the biogeochemical cycle of silicon and related weathering processes. Geochim. Cosmochim. Acta 61: 677-682.

Barboni D., Bonnefille R., Alexandre A. and Meunier J.C. 1999. Phytoliths as paleoenvironmental indicators, west Side Middle Awash Valley, Ethiopia. Palaeogeogr. Palaeoclimatol. Palaeoecol. 152: 87-100.

Bartoli F. 1986. Les Cycles biogéochimiques dans les écosystèmes forestiers tempérés. Sci. Géol. Bull. 39: 195-209.

Bluth G.J.S. and Kump L.R. 1994. Lithologic and climatologic controls of river chemistry. Geochim. Cosmochim. Acta 58: 2341-2359.

Bonnet L. 1964. Le peuplement thécamoebien des sols. Rev. Ecol. Biol. Sol. 1: 123-408.

Braun J.J., Bedimo Bedimo J.P., Robain H., Nyeck B., Ndam Ngoupayou J. and Olivié-Lauquet G. 1998. Fonctionnement des écosystèmes tropicaux humides influence sur les ressources hydriques et la qualité des eaux. Exemple du bassin fluvial du Nyong (Sud Cameroun). In: Vicat J.P. and et Bilong P. (eds), Géosciences au Cameroun. Editions GEOCAM, Press. Univ., Yaoundé I, pp. $23-40$

Braun J.J., Ndam Ngoupayou J., Viers J., Dupré B., Bedimo Bedimo J.P., Boeglin J.M., Robain H., Nyeck B., Freydier R., Sigha Ngamdjou L., Rouiller J. and Muller J.P. Current versus past weathering mass balance in humid tropical ecosystem: Nsimi Site (South Cameroon). Geochim. Cosmochim Acta. in press.

Bremond L., Alexandre A., Hely C. and Guiot J. 2004a. A phytolith index as a proxy of tree cover density in tropical areas: calibration with Leaf Area Index along a forest-savanna transect southeastern Cameroon. Global and Planetary Change. In press.

Bremond L., Alexandre A., Véla E. and Guiot J. 2004b. Advantages and disadvantages of phytolith analysis for the reconstruction of Méditerranean vegetation: an assessment based on modern phytolith, Pollen and botonical data (Luberon, France). Rev. Palaeobot. Palynol. 129: 213-218.

Clarke J. 2003. The occurrence and significance of biogenic opal in the regolith. Earth Sci. Rev. 60: $175-194$. 
Conley D.J. 1997. Riverine contribution of biogenic silica to the oceanic silica budget. Limnol. Oceanogr. 42: 774-777.

Conley D.J. 2002. Terrestrial ecosystems and the global biogeochemical silica cycle. Global Biogeochem. Cycles 16: 68/1-68/8.

DeMaster D.J. 1981. The supply and accumulation of silica in the marine environment. Geochim. Cosmochim. Acta 45: 1715-1732.

Fredlund G.G. and Tieszen L.T. 1994. Modern phytolith assemblages from the North American great plains. J. Biogeogr. 21: 321-335.

Harrison K.G. 2000. Role of increased marine silica input on paleo- $\mathrm{pCO}_{2}$ levels. Paleoceanography 15: 292-298.

Jansen J.H.F., Alderliesten C., Houston C.M., de Jong A.F.M., Der Borg K. and Van Iperen J.M. 1989. Aridity in equatorial Africa during the last 225,000 years: a record of opal phytoliths/ freshwater diatoms from the Zaire (Congo) deep-sea fan (Northeast Angola Basin). Radiocarbon 31: $557-569$.

Kelly E.F. 1990. Methods for extracting opal phytoliths from soil and plant material, Doc. of the department of agronomy. Colorado State University, 10pp.

Letouzey R. 1985. Notice de la carte phytogéographique du Cameroun au 1/500.000, Inst. Carte Intern, Yaoundé.

Lucas Y., Luizao F.J., Rouiller J. and Nahon D. 1993. The relationship between the biological activity of the rain forest and the mineral composition of the soils. Science 260: 521-523.

Melia 1984. The distribution and relationship between palynomorphs in aerosols and deep-sea sediments off the coast of northwest Africa. Marine Geol. 58: 345-371.

Meunier J.D., Alexandre A., Colin F. and Braun J.J. 2001. Interêt de l'étude du cycle biogèochimique du silicium pour interpréter la dynamique des sols tropicaux. Bull. Soc. Géol. 5: 533-538.

Meunier J.-D., Colin F. and Alarcon C. 1999. Biogenic silica storage in soils. Geology 27: 835-838.

Meybeck M. 1988. How to establish and use world budgets of riverine materials. In: Lerman A. and Meybeck M. (eds), Physical and Chemical Weathering in Geochemical Cycles. Kluwer Academic Publishers, pp. 247-272.

Michalopoulos P. and Aller R.C. 2004. Early diagenesis of biogenic silica in the Amazon delta: alteration, authigenic clay formation and storage. Geochim. Cosmochim. Acta 68(5): 1061-1085.

Moulton K.L., West J. and Berner R.A. 2000. Solute flux and mineral mass balance approaches to the quantification of plant effects on silicate weathering. Am. J. Sci. 300: 539-570.

Ndam Ngoupayou J. 1997. Bilans hydrogéochimiques sous forêt tropicale humide en Afrique: du bassin expérimental de Nsimi Zoétélé aux réseaux hydrographiques du Nyong et de la Sanaga (Sud-Cameroun). Thèse Univ, Paris VI214pp.

Ogden C.G. and Hedley R.H. 1980. An Atlas of Freshwater Testate Amoebae. Oxford University Press, British Museum.

Olivié-Lauquet G. 1996. Analyse des transferts solides dans la geosphère tropicale: exemple du bassin versant du Nyong (Cameroun). Thèse de doctorat de l'Université, Paris VII. 205 pp.

Olivié-Lauquet G., Allard T., Bertaux J. and Muller J.P. 2000. Crystal chemistry of suspended matter in a tropical hydrosystem, Nyong basin (Cameroon, Africa). Chem. Geol. 170: 113-131.

Piperno D.R. 1997. Phytoliths and microscopic charcoal from LEG 155: a vegetational and fire history of the Amazon Basin during the last 75 ky. Proceedings of the Ocean Drilling Program, Scientific Results. 155: 411-418.

Pokras S.E.M. and Mix A.C. 1985. Eolian evidence for spatial variability of Late Quaternary climates in Tropical Africa. Quat. Res. 24: 137-149.

Runge E.F. 1999. The opal phytolith inventory of soils in central Africa-quantities, shapes, classification and spectra. Rev. Palaeobot. Palynol. 107: 23-53.

Stallard 1988. Weathering and erosion in the humid tropics. In: Lerman A. and Meybeck M. (eds), Physical and Chemical Weathering in Geochemical Cycles. Kluwer Academic Publishers, pp. 225-246.

Tréguer P., Nelson D.M., Van Bennekom A.J., DeMaster D.J., Leynaert A. and Queguiner B. 1995. The silica balance in the world ocean: a reestimate. Science 222: 320-322. 
Twiss P.C. 1992. Predicted world distribution of C3 and C4 grass phytoliths. In: Rapp G. and Mulholland S.C. (eds), Phytolith Systematics. Emerging Issues. Adv Archeol. Mus. Sci. I, pp. $113-128$.

Twiss P.C., Suess E. and Smith R.M. 1969. Morphology classification of grass phytoliths. Proc. Soil Sci. Soc. Am. 33: 109-115.

Viers J., Dupré B., Braun J.J., Deberdt S., Angeletti B., Ndam Ngoupayou J. and Michard A. 2000. Major and trace element abundances and strontium isotopes in the Nyong basin rivers (Cameroon): constraints on chemical weathering processes and element transport mechanisms in humid tropical environments. Chemical Geology 169: 211-241.

Viers J., Dupré B., Polvé M., Schott J., Dandurand J.-L. and Braun J.-J. 1997. Chemical weathering in the drainage basin of a tropical watershed (Nsimi-Zoetele site, Cameroon), comparison between organic-poor and organic-rich waters. Chem. Geol. 140: 181-206.

Wilding L.P., Smeck N.E. and Drees L.R.L. 1989. Silica in soils: quartz, cristoballite, tridymite and disordered silica polymorphs. In: Dixon J.B. and Webb S.B. (eds), Minerals in Soil Environments. Soil Science Society of America Book 1, pp. 913-974.

Wüst R.A.J. and Bustin R.M. 2003. Opaline and Al-Si phytoliths from a tropical mire system of West Malaysia: abundance, habit, elemental composition, preservation and significance. Chem. Geol. 200: 267-292. 